\title{
1989-1990 ANNUAL BIBLIOGRAPHY OF ADMINISTRATIVE AND TECHNICAL COMMUNICATION IN CANADA
}

\author{
Jennifer J. Connor
}

"1990 Technical Communicator Salary Survey." STC Intercom 36 (November 1990): 1; insert.

Barnard, Sandie. Speaking Our Minds: A Guide to Public Speaking for Canadians. Scarborough: Prentice-Hall, 1990 .

Bell, Arthur, Kathleen Slaughter, and Stephen Long. Business Communication: Process and Practice. 1st Canadian ed. Agincourt: Gage, 1990.

Bist, Gary. "Training New Technical writers." IEEE Transactions on Professional Communication 33 (September 1990): $130-32$.

Blicq, Ron S. "Techniques for Designing and Writing videoscripts." Technostyle 8 (Winter 1989): 30-42.

Blicq, Ron S. Guidelines for Report Writing. 2nd ed. Scarborough: Prentice-Hall Canada, 1990.

Bossé-Andrieu, Jacqueline. "Les embûches de la féminisation du discours." Technostyle 9 (hiver 1990): 15-34.

Burgar, Maria. "No Footnotes Necessary." Bulletin of the Association for Business Communication 52 (1) (1989): 32-35. 
Cherry, Joan M., and So-Ryang Jackson. "Online Help: Effects of Content and Writing Style on User Performance and Attitudes." IEEE Transactions on Professional Communication 32 (December 1989): 294-99.

Dohaney, M.T. (Jean). "Teaching Procedure Writing: A Lesson Plan." Technostyle 8 (Spring/Summer 1989): 52-58.

Eldridge, Elaine. "Teaching Technical Writing in Canada." Journal of Technical Writing and Communication 20 (1990): 177-87.

Giltrow, Janet. Academic Writing: How to Read and Write Scholarly Prose. Peterborough: Broadview Press, 1990.

Giltrow, Janet. "Computers in Composition: Inscribing New Facts, Configuring New Knowledge." Technostyle 8 (Winter 1989): 1-15.

Harjee, Nimira, and Morgan White. "A 1989 Survey of Technical Communicators in Greater Toronto." Technical Communication 37 (1990): 420--22.

Ibrahim, A.M. "Acronyms Observed." IEEE Transactions on Professional Communication 32 (March 1989): 27-28.

Jordan, Michael P. "Some Inter-Paragraph Connections in Formal Prose." Technostyle 8 (Spring/Summer 1989): 14-37.

Jordan, Michael P. "The Reader Over Your Shoulder--Some Linguistic Background." Technostyle 9 (Winter 1990): $1-14$. 
Kanaganayakam, Chelva. "Electronic Conferencing--Its Form, Function and Potential for Technical Writing Instruction." Technostyle 8 (1989): 16-29.

Karis, William, and Stephen Doheny-Farina. "A Comparative Case Study of Technical Environmental Communication in Canada and the U.S." Technical Communication 37 (1990): 454-56.

Larivière, Louise. "Le résumé documentaire: problèmes et solutions." Technostyle 8 (printemps/ete 1989): $1-13$.

Larocque, Greg, Heidemarie MacLean, and william Marshall. Administrative Writing: Memos \& Letters. Ottawa: Minister of Supply and Services, 1988.

Lyons, Joseph T. Writing Fundamentals. 3rd. ed. Scarborough: Prentice-Hall Canada, 1990.

MacLennan, Jennifer. Effective Business Writing. Scarborough: Prentice-Hall, 1990.

Meney, Lionel. "Traduction ou nouvelle rédaction? Un exemple de difficultés posées par la traduction technique." Technostyle 8 (hiver 1989): 43-54.

Northey, Margot. Impact: A Guide to Business Communications. 2nd ed. Scarborough: Prentice-Hall, 1990.

Parker, Anne. "A Case-Study Workshop and a ProblemSolving Approach to Technical Communication." Technostyle 8 (Spring/Summer 1989): 38-51. 
Parker, Anne. "Teaching Technical Writing to First-Year Engineering Students: Classify, Analyze, Test, and Solve." Technical Writing Teacher 17 (Spring 1990): 95-103.

Randall, Neil. "Technical Communication Research at the Centre for Professional Writing, University of Waterloo." Technical Communication 37 (1990): 312-13.

Rhodes-Marriott, Tony. "Reflecting on STC in Canada." Technical Communication 37 (1990): 303-305.

Ross, Catherine Sheldrick, and Patricia Dewdney. Communicating Professionally: A How-To-Do-It Manual for Library Applications. New York, London: Neal Schuman, 1989.

Velte, Charles E. "Face Up to the Interface." IEEE Transactions on Professional Communication 33 (September 1990): 115-17.

Wegner, Diana. "The Role of the Reader in the Writing Process." Technostyle 9 (Winter 1990): 35-44. 


\title{
1991-1992 ANNUAL BIBLIOGRAPHY OF ADMINISTRATIVE AND TECHNICAL COMMUNICATION IN CANADA
}

\author{
Jennifer J. Connor
}

Blicq, Ron S. Communicating at Work: Creating Messages that Get Results. Scarborough: Prentice-Hall Canada, 1991 .

Collins, C. Edward. The Basics of Technical Writing and Speaking. Scarborough: Prentice-Hall Canada, 1991 .

Connor, Jennifer J. "History and the Study of Technical Communication in Canada and the United States." IEEE Transactions on Professional Communication 34 (1991): forthcoming.

Read, Hugh, and C. Edward Collins. English at Work: Communicating in Business and Industry. Scarborough: Prentice-Hall Canada, 1991.

Rodman, Lilita. "Anticipatory It in Scientific Discourse." Journal of Technical Writing and Communication 21 (1991): 17-27.

Rodman, Lilita. Technical Writing. Harcourt Brace Jovanovich, Canada, 1991.

Stewart, Kay I., and Marian Kowler. Forms of Writing: A Brief Guide and Handbook. Scarborough: Prentice-Hall Canada, 1991. 